\title{
Study on Building Safety Accident and Risk Management
}

\section{Puyang City Construction Engineering Safety Supervision and Management Station Henan Puyang 457000}

\section{Introduction}

\section{The Importance of Safety Risk Management in Con- struction Engineering}

In recent years, with the rapid development of the construction industry, the scale of construction is becoming increasingly large and complex, large buildings, high-rise buildings and underground construction continue to emerge, with the complex structure design, special performance building materials, new construction technology increase the difficulty of construction; At the same time, the safety of construction enterprises, the quality of the safety of employees, the whole society's security atmosphere is still at a low level, resulting in frequent construction safety accidents, according to statistics in China from 2015 to 2016 due to the increasing number of construction accidents, safety production situation is grim. At present, the construction industry is the most dangerous industry in China's industrial sector after the mining industry. The annual construction safety accidents not only cause huge economic losses, but also cause a lot of casualties, which seriously affect the social stability and the healthy development of the industry.

Table 12015 - 2016 China's main indicators of construction accidents

\begin{tabular}{|c|c|c|}
\hline Year & 2015 & 2016 \\
\hline $\begin{array}{c}\text { Number of } \\
\text { accidents }\end{array}$ & 538 & 634 \\
\hline $\begin{array}{c}\text { The number of } \\
\text { death }\end{array}$ & 718 & 735 \\
\hline
\end{tabular}

Data from the network
With the rapid development of science and technology, domestic residents living standards and quality of life in the continuous improvement. In such circumstances, various types of buildings came into being. In the construction industry under the rapid development, is bound to bring a lot of security risks. In general, there are many unpredictable risk factors in construction that threaten the safety of human life and property. As the architectural modeling with diversity, complexity and other characteristics, often resulting in construction activities in the safety accidents frequent. In the construction, the staff need long-term to be in the open air construction, which undoubtedly has a higher risk. At the same time, in the construction will be affected by the natural environment, especially in the latter part of the project planning and project implementation, often by the natural conditions of the decision, it is difficult to predict the probability of risk, it is difficult to predict the risk for the impact of the construction project. These unpredictable risks will not only threatening the personal safety of the staff, but also for the entire construction enterprises to bring immeasurable losses. Combined with the characteristics of construction projects, whether it is engineering supervision workers or specific construction staff should be combined with the actual situation of construction projects and establish a corresponding awareness of security and only the construction workers have a strong sense of security precautions in order to ensure the construction smoothly and safe.

\begin{abstract}
The development of the times is extremely rapid. The construction industry has occupied a very important position in the national economy and made an indelible contribution in promoting the social and economic development. However, the construction industry covers a wide range of areas, long construction period, personnel mobility, complex types of work, prone to security incidents. The safety accidents have not only threatened the safety of our people's lives and property, but also brought great losses to the construction industry. Therefore, the construction industry should attach greatly to the importance to safety accidents, strengthen the management of construction safety, and all the buildings that affect the safety of construction factors strangled in the cradle, thus promoting the construction industry's stable, sustained and healthy development.
\end{abstract}

Key words: Construction safety; accident; risk management

Published online: 15th July, 2017

\section{Analysis on the Cause of Building Safety Accident}

The reasons for the occurrence of safety accidents are very complicated. Since the 1950s, scholars at home and abroad have done a lot of research on them, and put forward a number of causal causes such as causal chain, energy 
accident transfer and dynamic change of trajectory. The author has carried on the extensive research through the questionnaires such as the cause of the accident accident, the typical case analysis and the expert interview, and thinks that the building safety management is a complex system composed of man-machine-environment, which has the characteristics of openness and integrity The open performance in the building security system exists in a certain environment and other systems as the environment for the material, energy, information exchange and in the exchange of continuous optimization of the dynamic development process. The overall performance of the building safety system is a combination of planning, design, construction, supervision and many other elements of the organic whole and play an important role. If there is a problem with any factor, the whole system fails. in general, the construction safety accident whether is caused by the insecurity of the internal or external existence, the insecure state of the product leads to the abnormal system order.

\subsection{Internal Causes of Building Safety Accidents}

Aiming at the identification of risk factors in class $\mathrm{A}$, this paper uses the accident tree method which can qualitatively analyze and analyze the accident, such as falling, collapsing, object striking, and lifting injury and so on. Analysis of the accident from the people to prevent unsafe behavior and the insecure state of the construction of the accident tree, given the accident tree map, see Figure 1.

According to the accident tree structure shown in Fig. 1, after the accident statistical analysis, the basic event occurrence probability and the structural function of the accident tree are determined as follows:

$\mathrm{T}=(\mathrm{X} 1+\mathrm{X} 2+\mathrm{X} 3+\mathrm{X} 4+\mathrm{X} 5+\mathrm{X} 6+$ $\mathrm{X} 7)(\mathrm{X} 8+\mathrm{X} 9+\mathrm{X} 10+\mathrm{X} 11+\mathrm{X} 12)$

According to the structure of the accident tree and the relevant statistical data, the order of structural importance is as follows:

$\mathrm{I}(8)=\mathrm{I}(9)=\mathrm{I}(10)=\mathrm{I}(11)=\mathrm{I}(12)>\mathrm{I}(4)$ $=\mathrm{I}(1)=\mathrm{I}(2)=\mathrm{I}(3)=\mathrm{I}(5)=\mathrm{I}(6)=\mathrm{I}(7)$

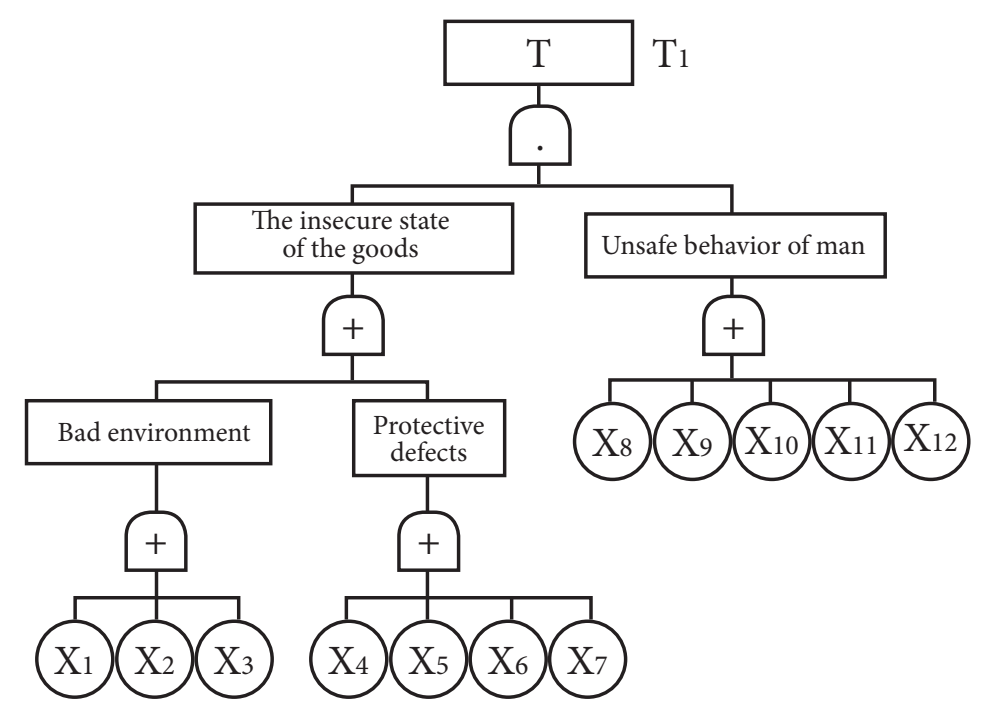

Figure 1 Construction system accident tree

The order of the cause of the Class A accident can be followed: $X 8, X 9$, $\mathrm{X} 10, \mathrm{X} 11, \mathrm{X} 12, \mathrm{X} 4, \mathrm{X} 1, \mathrm{X} 2, \mathrm{X} 3, \mathrm{X} 5, \mathrm{X} 6$, $X 7$. The specific meaning is shown in Table 2. From the analysis of Figure 1 and Table 2, in the high fall, collapse, object strikes, lifting injuries and other four major accidents, technical measures are not in place, the system is not implemented, the safety awareness of operating personnel, adventure, illegal operation and other factors play a major role, but also the focus of corporate governance prevention and control.

\subsection{Building safety accident exter- nal causes}

At present, China's construction safety accidents frequent, in addition to internal causes, the external cause is also a greatly impacted, mainly for the safety regulatory functions of the department is unclear, the construction market legal environment is not standardized, the main building responsibility is not clear, as follows :

(1) Safety supervision function is not clear. Construction project safety management work in the decentralized management status, departmental functions cross, long supervision, and the responsibility is unclear, it is difficult to form a standardized management model.

(2) The construction market legal environment is not standardized and not perfect. At present, China's construction industry laws and regulations system is not sound, operability is not strong, such as dismemberment contract, subcontracting and other acts of qualitative are not allowed, the lack of specific definition of the standard; the construction unit of the legal liability is too principle, the relevant penalties lack of operability; no perfect project quality insurance laws and regulations; do not have the appropriate qualifications and quality assurance capabilities of enterprises and individuals through the certificate anchored, fraud and other forms into the construction market, seriously disrupt the market order.

(3) The construction of the main responsibility of the linkage system has not yet formed. China's construction safety management mainly to the post-type, empirical-based, is a passive management model, security management focused on the construction site management, owners, design side, bearing (sub) package, government, supervision unit, intermediary advisory bodies and other common responsibility is not clear, the accident investigation is not in place, the whole process, all-round supervision and linkage system has not yet formed.

\subsection{Building safety accident cause system}

On the basis of the above analysis, this paper analyzes the causes of the building safety accidents, such as the main factors involved in the construction safety management, as shown in the figure 2 , the square 


\begin{tabular}{|c|c|c|c|c|c|}
\hline \multirow{2}{*}{$\frac{\text { No }}{1}$} & \multirow{2}{*}{$\frac{\text { Symbol }}{T}$} & \multicolumn{4}{|c|}{ Meaning } \\
\hline & & Falling from height & Collapsed & Object hit & Lifting damage \\
\hline 2 & $X_{1}$ & $\begin{array}{l}\text { The work surface is } \\
\text { smooth }\end{array}$ & Pit side of the pile & Bad weather & Scene chaos \\
\hline 3 & $x_{2}$ & $\begin{array}{l}\text { Wind and other harsh } \\
\text { conditions }\end{array}$ & $\begin{array}{l}\text { Heavy rain and other } \\
\text { adverse weather con- } \\
\text { ditions }\end{array}$ & Noise environment & $\begin{array}{l}\text { Wind and other harsh } \\
\text { conditions }\end{array}$ \\
\hline 4 & $x_{3}$ & Poor lighting & $\begin{array}{l}\text { Groundwater level } \\
\text { change }\end{array}$ & Proceedings & $\begin{array}{l}\text { Lifting machinery } \\
\text { based wading }\end{array}$ \\
\hline 5 & $X_{4}$ & $\begin{array}{l}\text { Improper clinical } \\
\text { protection }\end{array}$ & $\begin{array}{l}\text { Foundation pit support } \\
\text { improper }\end{array}$ & $\begin{array}{l}\text { Drawings, stacking frame } \\
\text { support improper }\end{array}$ & Load limiter failure \\
\hline 6 & $X_{5}$ & $\begin{array}{l}\text { Improper hole pro- } \\
\text { tection }\end{array}$ & $\begin{array}{l}\text { Frame body erection } \\
\text { is not standardized }\end{array}$ & $\begin{array}{l}\text { No protection against } \\
\text { cross work }\end{array}$ & Controller failure \\
\hline 7 & $x_{6}$ & $\begin{array}{l}\text { Scaffolding guard } \\
\text { railings improperly }\end{array}$ & $\begin{array}{l}\text { After installation } \\
\text { snacks fixed is not } \\
\text { strong }\end{array}$ & $\begin{array}{l}\text { Ground feed without } \\
\text { protection }\end{array}$ & $\begin{array}{l}\text { Stroke limit device } \\
\text { failure }\end{array}$ \\
\hline 8 & $x_{7}$ & $\begin{array}{l}\text { Seat belt is used } \\
\text { improperly }\end{array}$ & $\begin{array}{l}\text { The template is erect- } \\
\text { ed improperly }\end{array}$ & Improper use of helmets & $\begin{array}{l}\text { Electrical safety } \\
\text { device failure }\end{array}$ \\
\hline 9 & $X_{8}$ & $\begin{array}{l}\text { Individuals do not } \\
\text { qualify }\end{array}$ & Adventure to enter & Operational error & $\begin{array}{l}\text { Unqualified installa- } \\
\text { tion, removal }\end{array}$ \\
\hline 10 & $X_{9}$ & $\begin{array}{l}\text { Personal error unex- } \\
\text { pectedly }\end{array}$ & Technical misconduct & Illegal throwing & $\begin{array}{l}\text { Hanging point and } \\
\text { the state is not tight } \\
\text { problem }\end{array}$ \\
\hline 11 & $x_{10}$ & Adventure & Stacking is too high & $\begin{array}{l}\text { Unrelated personnel into } \\
\text { demolition area }\end{array}$ & $\begin{array}{l}\text { Not according to } \\
\text { "ten does not hang" } \\
\text { requirements }\end{array}$ \\
\hline 12 & $x_{11}$ & $\begin{array}{l}\text { Subject to external } \\
\text { shock }\end{array}$ & Scaffolding overload & $\begin{array}{l}\text { Lifting hoisting instruc- } \\
\text { tions improperly }\end{array}$ & Improper use of sling \\
\hline 13 & $X_{12}$ & Physical discomfort & $\begin{array}{l}\text { Not according to the } \\
\text { program construction }\end{array}$ & Upper hopper overload & $\begin{array}{l}\text { Suspension of choice } \\
\text { improper }\end{array}$ \\
\hline
\end{tabular}

Table 2 Building construction accident tree symbol and meaning

module represents the external factor involved in the construction safety management, which belongs to the external factor of the project safety accident. The oval box means the in-

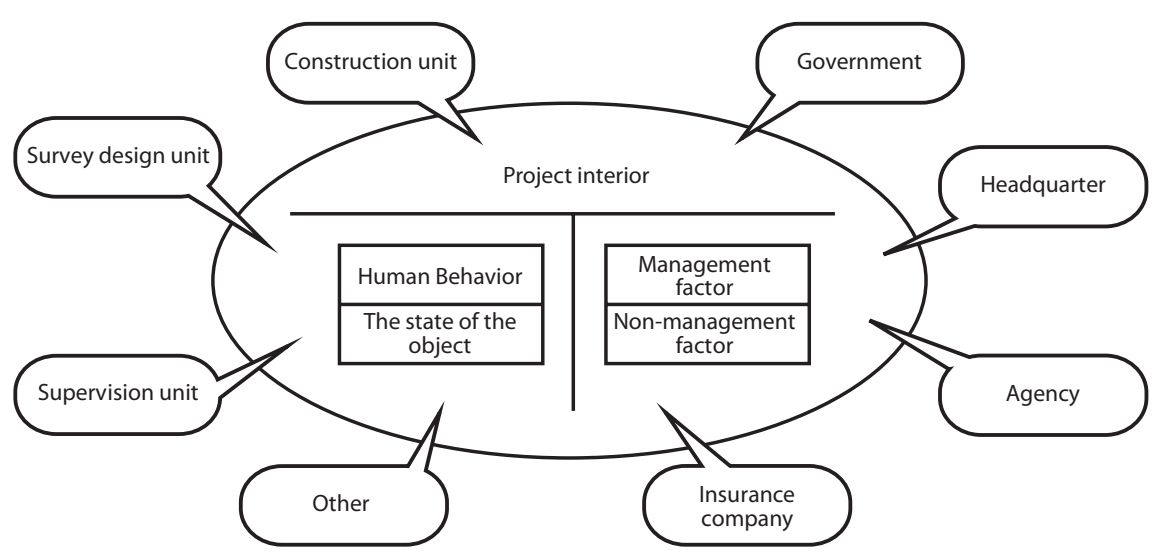

Figure 2 Building safety accident internal and external causes system project safety accident.

\section{Meas es for Risk Management of Building Safety Accidents} safety management of the project and belong to the internal factors of the

\subsection{Establish and improve the se- curity risk early warning disposal mechanism}

At present, there are already more perfect theories about the safety accidents of construction projects. According to these theories, it is possible to realize the construction of safety risk early warning disposal mechanism so as to timely discover the potential risks of construction safety and to solve them in time.

(1) Based on the theory of comprehensive factors, we can construct a dynamic visualization model, which requires the use of BIM information 
model technology, based on the relevant data of construction projects to build a preliminary security model. And then according to the actual progress of the project, enter the actual engineering data, which deduce the future changes in the security model, early detection of vulnerable security nodes and its prior control.

(2) Based on the domino theory, you can take the way to cut off the accident chain to build a security risk early warning disposal mechanism. In the construction project, leading to the same security accident chain is not only one, so to prevent the occurrence of security incidents, the need for multiple accident chain to achieve effective blocking. Through the analysis can be found, these different accident chain, with some overlapping nodes, these nodes is the key to prevent security risks, reasonable control of these nodes, you can achieve multiple accident chain at the same time. construction units and subcontractors between the three parties to coordinate the relationship between the interests of its coordination. Under the relevant laws and regulations, the construction unit should be mandatory for insurance. Insurance rate also need to be determined in accordance with market conditions. At the same time, the security premium to pay the situation and the credibility of enterprises, performance and related to strengthen the role of economic regulation. So, you can force the construction units to pay attention to the security issues.

\subsection{Consolidate the basis of build- ing safety risk prevention and con- trol}

(1) To all the participants in the construction of safety education, to recognize the formation of security incidents and specific reasons, starting from their own standards in strict accordance with the standard work to solve the problem to avoid the expansion of the formation of mass incidents, which will affect the control in the minimum range. (4) Through the contract, insurance, security transfer risk. Due to the construction industry market there is a certain opaque situation, making part of the risk is difficult to avoid. Therefore, it is possible to pass on the risk of occurrence of this part of the probability of contracting, insurance or guarantee to other construction units, insurance companies or guarantee companies, thus avoiding the impact on the unit.

\subsection{Improve the safety of quantita- tive assessment standards}

In addition to the above measures, but also through the quantitative assessment of the safety indicators, the project risk assessment and management, good security risk prevention and control. For example, according to the enterprise's previous safety record to develop a set of safety quan-

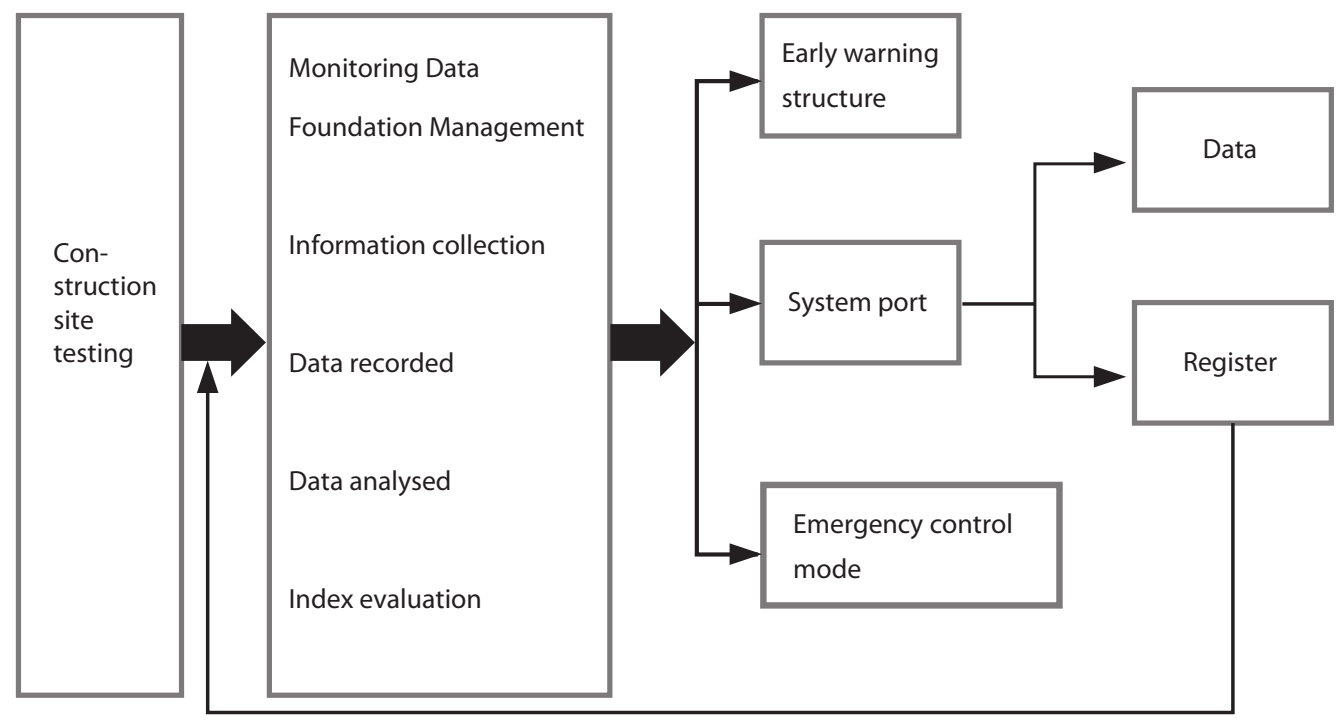

Figure 3 building construction site safety early warning of the overall flow chart

3.2 Strengthen the construction safety management regulation and control

(1) According to laws and regulations to clarify the responsibility of the parties, when signing the contract, it should be the responsibility in the division of construction to avoid the occurrence of security issues prevarication. (2) The use of economic levers to adjust the safety accident, through economic interests to strengthen the construction units, avoid the formation of security risks. (2) The development of safety quantitative indicators, the various aspects of the safety of construction projects to quantify the degree of safety, in order to measure the degree of security risk level, so that the early targeted to prevent disposal. (3) Improve the risk response mechanism, that is, for possible security risks, in advance to develop a good solution to ensure that in the event of a security incident can be the first time to respond quickly to titative indicators, the accident damage rate, time loss rate, labor claims and other detailed definition for the disposal of security issues to provide a reliable basis.

\subsection{Safety training for construction personnel}

Employee enterprises should meet the safety training and training of on-site construction workers and carry out their assessment on a regular basis. Only after a series of require- 
ments for safety training can they be engaged in this work to further improve the safety awareness of construction workers. In addition, some special positions, the construction staff must be holders of posts, no relevant qualifications of the staff cannot be posts, to avoid security incidents. Regular safety checks for those who found the illegal operation of the staff to be informed criticism and its implementation of safety education, so as to improve production safety awareness, the performance of the staff, give timely encouragement, including material incentives and spiritual incentives. Thereby en- hancing the enthusiasm and initiative of the staff. Construction companies must be aware that only from the root to find out the reasons for the impact of construction safety, in order to really ensure the safety of construction.

\section{Conclusion}

[1] Wang Di Di. Talking about the Application of Accident Tree Analysis in School Sports Safety Risk Management [J]. Sports, 2011,03: $1-3+13$.

[2] Wu Jianjin. Construction Safety Accident Analysis and Safety Management Research [J]. Construction
Safety, 2011,09: 4-7.

[3] Yang Fang. Civil Building Safety Accident Causes Analysis and Early Warning Management [J]. Sichuan Cement, 2015, 10: 349.

[4] Wang Xiaodan. Construction Safety Accident Analysis and Application of PDCA Cycle Management [J]. Anhui Architecture, 2016,04: 303-304.

[5] Wang Chengan. Construction Safety Accident Causes Analysis and Early Warning Management Research [J]. China High-tech enterprises, 2008,19: 235. 